\title{
RESPON VARIETAS PADI IR64 DAN IR64-SUB 1 TERHADAP PERENDAMAN DAN PEMUPUKAN N
}

\section{Response of Rice Varieties (IR64 and IR64-Sub 1) to the time of submergence and $\mathbf{N}$ Application}

\author{
Ikhwani1), Gagad R.Pratiwi') dan A. Karim Makarim²) \\ 1) Puslitbang Tanaman Pangan, Jl. Merdeka 147 Bogor \\ 2) Balai Besar Penelitian Tanaman Padi, Jl. Raya 9 Sukamandi, Subang, Jawa Barat
}

\begin{abstract}
There are many new rice varieties have been produced, introduced and breed at IRRI and the other National Agriculture Research Institutes that are tolerance to submergence condition to anticipate global warming and flash flooding around the world. Among others are IR64-Sub 1, Suwarna-Sub 1, Inpara-1, Inpara-2, Inpara-3 etc. However, those new varieties have not been tested widely yet, and the method of rice cultivation under submergence condition have not been adjusted, including the nutrient management.

A greenhouse experiment was conducted at Muara Research Station, Bogor during 2008 dry season. The objectives of this experiment are (1) to study the effects of time of submergence and $N$ application on plant growth and yield of IR64 and IR64-Sub 1 rice varieties; (2) to find the best nutrient management for submergence rice varieties. The experiment was conducted during 2008 dry season at greenhouse, Muara Research station, Bogor. The design of the experiment was a Completely Randomized Factorial Design with three replications. Factor 1 is rice variety (IR64 and IR64-Sub 1); Factor 2 is time of submergence (without submergence or control, submergence at vegetative phase (15 to 25 d.a.t), and at generative phase (35 to 45 d.a.t)). Factor 3 is $N$ application, namely (F1) $300 \mathrm{~kg}$ Urea/ha $3 x$ applications at 7 d.a.t- 30 d.a.t - 55 d.a.t; (F2) Mudball urea -300 kg Urea/ha applied once at 7 d.a.t. (F3) compost; and (F4) compost and urea; (F5) Urea and silikat. urea- $N$ application at four time 0 d.a.t -7 d.a.t - 30 d.a.t -55 d.a.t (factor $C$ ).

The results of experiments showed that submergence changes rice plant growth pattern (mainly tiller number and plant height), increased dry grain weight of IR64, namely $35.9 \mathrm{~g}$ at early vegetatif phase and $29.9 \mathrm{~g}$ at late vegetatif phase, while for IR64-Sub $132.6 \mathrm{~g}$ and $30.3 \mathrm{~g}$ at the same respective phase. Mudball urea and silicate application improved plant resistant to submergence and increase rice yield.
\end{abstract}

Key words: Submergence, rice tolerant, $N$ application, nutrient management

\section{PENDAHULUAN}

Banjir yang sering terjadi di kawasan pertanian di Indonesia berdampak terhadap meningkatnya kerugian petani, kehilangan hasil, dan kerusakan infrastruktur. Rendaman yang mengakibatkan cekaman terhadap tanaman padi di wilayah Selatan dan Asia tenggara diperkirakan mencapai 15 juta hektar setiap tahunnya (Septiningsih et al., 2008). Luas areal pertanaman padi yang mengalami cekaman rendaman karena banjir diperkirakan akan semakin bertambah karena terjadi peningkatan curah hujan dan kenaikan permukaan air laut akibat terjadinya pemanasan global (CGIAR, 2006; Widiarta, 2007). Potensi areal terkendala cekaman rendaman untuk dikembangkan menjadi lahan pertanian masih sangat luas, untuk areal pasang surut diperkirakan seluas 9.53 juta ha dan rawa lebak seluas 13.3 juta ha (Nugroho et al., 1993; WidjajaAdhi et al., 1995).

Untuk sentra produksi pertanian seperti padi, meskipun padi merupakan tanaman yang dapat beradaptasi pada kondisi tanah yang airnya berlebih, namun secara umum tanaman padi akan mati jika seluruh bagian tanamannya terendam selama seminggu (Ito et al., 1999). Tanaman padi yang masih muda biasanya lebih rentan terhadap cekaman rendaman (Jackson dan Ram, 2003), terutama pada daerah rendah, semakin seringnya banjir berarti akan semakin seringnya gagal panen atau kehilangan produksi akibat kebanjiran dengan lama dan tinggi yang bervariasi.

Faktor utama penyebab rusaknya tanaman dalam kondisi terendam akibat kekurangan $\mathrm{O}_{2}$ dan $\mathrm{CO}_{2}$ sehingga menghambat respirasi (kurang energi untuk tumbuhkembang) dan fotosintesis. Sebaliknya, hormon tanaman seperti etilen dalam bentuk gas yang diproduksi di dalam tanaman dilaporkan (Jackson et al., 1987) terakumulasi dalam jaringan hingga konsentrasinya $0,49 \mu \mathrm{M}$ pada varietas IR42 umur 12 hst ketika terendam selama 55 jam. Etilen inilah yang berpengaruh terhadap (1) pemanjangan batang tanaman padi (elongation) selama tanaman terendam (Lee and Lin 1996); dan (2) menguningnya daun (senescene) (Jackson et al., 1987; Ella et al., 2003) yang tentunya akan menghambat fiksasi karbon dalam fotosintesis pada saat maupun setelah terendam.

Tanaman merespon kondisi cekaman rendaman dengan dua cara, yaitu (a) pemanjangan buku-buku (internode) sehingga daun mampu menggapai permukaan air, dan (b) mempertahankan proses fisiologi tanaman sehingga mampu bertahan dan melanjutkan kehidupannya 
(Mackill et al., 1999). Catling (1992) mendefinisikan tanaman padi toleran terhadap cekaman rendaman jika mampu melanjutkan kelangsungan hidupnya setelah terendam seluruh bagian tanamannya selama 10-15 hari.

Keragaman varietas-varietas padi yang ada maupun yang sengaja dirakit terhadap ketahanan perendaman perlu diinventarisir. Informasi dan data tersebut sangat diperlukan untuk mendukung program pemuliaan tanaman padi tahan rendaman, program pengelolaan tanaman/budidaya padi untuk daerah rawan banjir, dan langkah kebijakan untuk antisipasi dampak banjir di masa mendatang. Diharapkan keberhasilan penanggulangan dampak negatif rendaman, akan menambah luas potensi areal pengembangan padi.

Tujuan penelitian adalah untuk mengetahui respon dua varietas padi (IR64 dan IR64-Sub 1) terhadap perendaman pada dua fase pertumbuhan dengan lima kombinasi pemberian pupuk $\mathrm{N}$.

\section{BAHAN DAN METODE}

Percobaan dilaksanakan di Kebun Percobaan (KP) Muara, Bogor, Jawa Barat selama satu musim tanam (MK 2008). Rancangan percobaan adalah Faktorial Acak Kelompok $(2 \times 3 \times 5)$ dengan tiga ulangan. Faktor pertama varietas (1) IR64 (V1) dan (2) IR64-Sub 1(V2), Faktor kedua waktu perendaman: (1) tanpa perendaman/ kontrol (S0); (2) Perendaman selama 10 hari pada fase vegetatif awal atau 15 hst s/d 25 hst (S1); dan (3) Perendaman selama 10 hari pada fase vegetatif akhir atau 35 hst s/d 45 hst (S2). Perendaman tanaman dilakukan dalam air jernih yang ditampung dengan kantung plastik besar selama 10 hari pada masing-masing fase perendaman. Faktor ketiga adalah 5 kombinasi pemberian pupuk $(\mathrm{F})$ seperti pada Tabel 1. Bibit padi berumur 14 hari ditanam dalam pot berisi 10 $\mathrm{kg}$ tanah per pot sebanyak 3 bibit. Pada umur 28 dan 50 hst tanaman disampling dan disisakan satu rumpun per pot sampai panen.
Tabel 1. Perlakuan Waktu Pemberian dan Jenis Pupuk

\begin{tabular}{|c|c|c|c|c|}
\hline \multirow[t]{2}{*}{ Perlakuan 1/ } & \multicolumn{4}{|c|}{ Waktu dan dosis pemberian pupuk (hst) $\mathrm{kg}^{-1} / \mathrm{ha}$} \\
\hline & $0 \mathrm{hst}$ & $7 \mathrm{hst}$ & $30 \mathrm{hst}$ & $55 \mathrm{hst}$ \\
\hline$F 1=$ Urea pril & & 100 & 100 & 100 \\
\hline $\mathrm{F} 2=$ Urea granul & 300 & & & \\
\hline $\mathrm{F} 3=\mathrm{Kompos}$ & $\begin{array}{l}\text { Kompos } 2 \\
\text { t/ha }\end{array}$ & $\begin{array}{l}\text { (dianali- } \\
\text { sis N) }\end{array}$ & & \\
\hline $\begin{array}{c}\mathrm{F} 4=\text { Kompos }+ \\
\text { urea }\end{array}$ & $\begin{array}{l}\text { Kompos } 1 / 2 \\
\text { dosis } \\
\left(1 t^{-1 / h a)}\right.\end{array}$ & & & $\begin{array}{l}\text { Urea } 1 / 2 \\
\text { dosis }(150 \\
\left.\mathrm{kg}^{-1} / \mathrm{ha}\right)\end{array}$ \\
\hline F5 $=$ Urea+Silikat & & $100+20$ & $100+20$ & $100+20$ \\
\hline
\end{tabular}

1/ Pupuk P dan K diberikan ke semua perlakuan sebanyak 100kg SP36/ha dan $100 \mathrm{~kg} \mathrm{KCl} /$ ha pada saat tanam

Pada percobaan ini tanaman direndam didalam bak plastik yang dibiarkan terbuka sehingga sirkulasi udara dapat berlangsung dengan baik dengan suhu maksimum minimum yang stabil.

Pengamatan dilakukan terhadap tinggi tanaman dan jumlah anakan, selanjutnya komponen hasil yang diamati adalah jumlah, panjang dan gabah isi per malai, bobot 1000 butir, dan bobot gabah total. Analisis data dilakukan menggunakan Analisis Statistik Balanced ANOVA dari program Minitab, menggunakan model sebagai berikut:

$$
y_{i j k l}=\mu+a_{i}+b_{j}+c_{k}+a b_{i j}+a c_{i k}+b c_{j k}+a b c_{i j k}+e_{l(i j k)}
$$

Data pengamatan dimasukkan ke dalam sheet sesuai prosedur MINITAB dan dirun menghasilkan daftar sidik ragam (ANOVA) untuk semua peubah kemudian dilanjutkan dengan analisis yang sesuai untuk rancangan Acak Kelompok Faktorial.

\section{HASIL DAN PEMBAHASAN}

Tanah yang digunakan pada percobaan ini memiliki sifat fisika dan kimia sebagai berikut: $\mathrm{pH} 5.5, \mathrm{~N}$ organik $0.257 \%$, P tersedia (mg/100g) Bray-1 $6.6 \mathrm{mg} \mathrm{kg}^{-1} \mathrm{P}, \mathrm{Kdd}$ $0.25 \mathrm{cmol}^{+} \mathrm{kg}^{-1}$, dengan suhu udara maximum-minimum rata-rata $27.8{ }^{\circ} \mathrm{C}$ dan $21.2^{\circ} \mathrm{C}$. Ringkasan hasil analisis statistik pengaruh semua perlakuan terhadap semua peubah yang diamati disajikan pada Tabel 2.

Tabel 2. Analisis Statistik Respon Varietas terhadap Perendaman dan Pengelolaan Hara, KP Muara Bogor MK 2008

\begin{tabular}{|c|c|c|c|c|c|c|c|}
\hline $\begin{array}{l}\text { Sumber } \\
\text { keragaman }\end{array}$ & Hasil GKG & Panjang malai & $\begin{array}{l}\text { Jumlah gabah } \\
\text { isi per pot }\end{array}$ & $\begin{array}{l}\text { Jumlah gabah } \\
\text { hampa per pot }\end{array}$ & $\begin{array}{l}\text { Persentase } \\
\text { gabah isi }\end{array}$ & $\begin{array}{l}\text { Jumlah malai } \\
\text { per pot }\end{array}$ & Bobot 1000 butir \\
\hline Rendaman (S) & $* *$ & $* *$ & $* *$ & ** & $* *$ & $* *$ & $* *$ \\
\hline Varietas (V) & * & ** & $\mathrm{ns}$ & $\mathrm{ns}$ & ns & ns & $\mathrm{ns}$ \\
\hline Pupuk (F) & $* *$ & $* *$ & $* *$ & $*$ & ns & $* *$ & $* *$ \\
\hline$S \times V$ & $\mathrm{~ns}$ & $* *$ & $\mathrm{~ns}$ & $\mathrm{~ns}$ & $\mathrm{~ns}$ & $*$ & $\mathrm{~ns}$ \\
\hline$S \times F$ & $*$ & ns & $*$ & $\mathrm{~ns}$ & ns & $\mathrm{ns}$ & $* *$ \\
\hline $\mathrm{V} \times \mathrm{F}$ & $*$ & ns & ns & ns & ns & ns & ns \\
\hline$S \times V x F$ & $\mathrm{~ns}$ & $\mathrm{~ns}$ & ns & $\mathrm{ns}$ & ns & $\mathrm{ns}$ & $\mathrm{ns}$ \\
\hline
\end{tabular}

Keterangan: ns = tidak nyata; $*$ = nyata; dan $* *=$ sangat nyata

Perlakuan perendaman dan pemupukan mempengaruhi panjang malai sedangkan pemupukan sangat berbeda nyata terhadap semua komponen hasil. Demikian juga untuk semua komponen hasil berpengaruh sangat nyata akibat adanya perendaman (Tabel 2). Jumlah malai per pot juga dipengaruhi oleh adanya interaksi antara perendaman dan varietas. Bobot 1000 butir dipengaruhi oleh interaksi antara perendaman dan aplikasi pupuk tetapi tidak berbeda nyata untuk varietas. 
Pengaruh perendaman dan pemupukan terhadap tinggi tanaman dan Jumlah anakan pad tiap fase pertumbuhan.

Dari hasil percobaan baik pada fase vegetatif maupun fase primordia menunjukkan bahwa kedua varietas yang diuji secara umum masih dapat bertahan hidup didalam air. Kemampuan hidup dan ketahanan tanaman untuk terus bertambah tinggi dan menghasilkan jumlah anakan masing-masing varietas berbeda.

Padi varietas IR64 lebih tinggi dibandingkan dengan IR64-Sub 1. Dari hasil analisa sidik ragam varietas mempengaruhi tinggi tanaman pada umur 14 hst, 28 hst dan perlakuan perendaman dan varietas mempengaruhi tinggi tanaman pada umur 42 hst dan 56 hst. Selama perendaman terjadi pertambahan tinggi tanaman yang sangat nyata pada varietas IR64 yang berusaha untuk melewati permukaan air melebihi varietas IR64-Sub 1. Hal ini menunjukkan adanya aktivitas fisiologis pada tanaman yang terendam. Setelah mengalami perendaman selama 10 hari pemulihan penambahan jumlah anakan baru mulai saat umur tanaman 42 hst.

Pada fase primordia, tanaman lebih tinggi dibandingkan kontrol, terutama pada saat tanaman berumur 70 hst sampai umur 80 hst. Hal ini menunjukkan pengaruh perendaman secara fisiologi menyebabkan ketidakstabilan pertumbuhan tanaman. Tinggi tanaman kembali stabil pada saat tanaman berumur 84 dan 91 hingga menjelang panen.

Pengaruh waktu perendaman terhadap tinggi tanaman kedua varietas (IR64 dan IR64-Sub 1) disajikan pada Gambar 1.

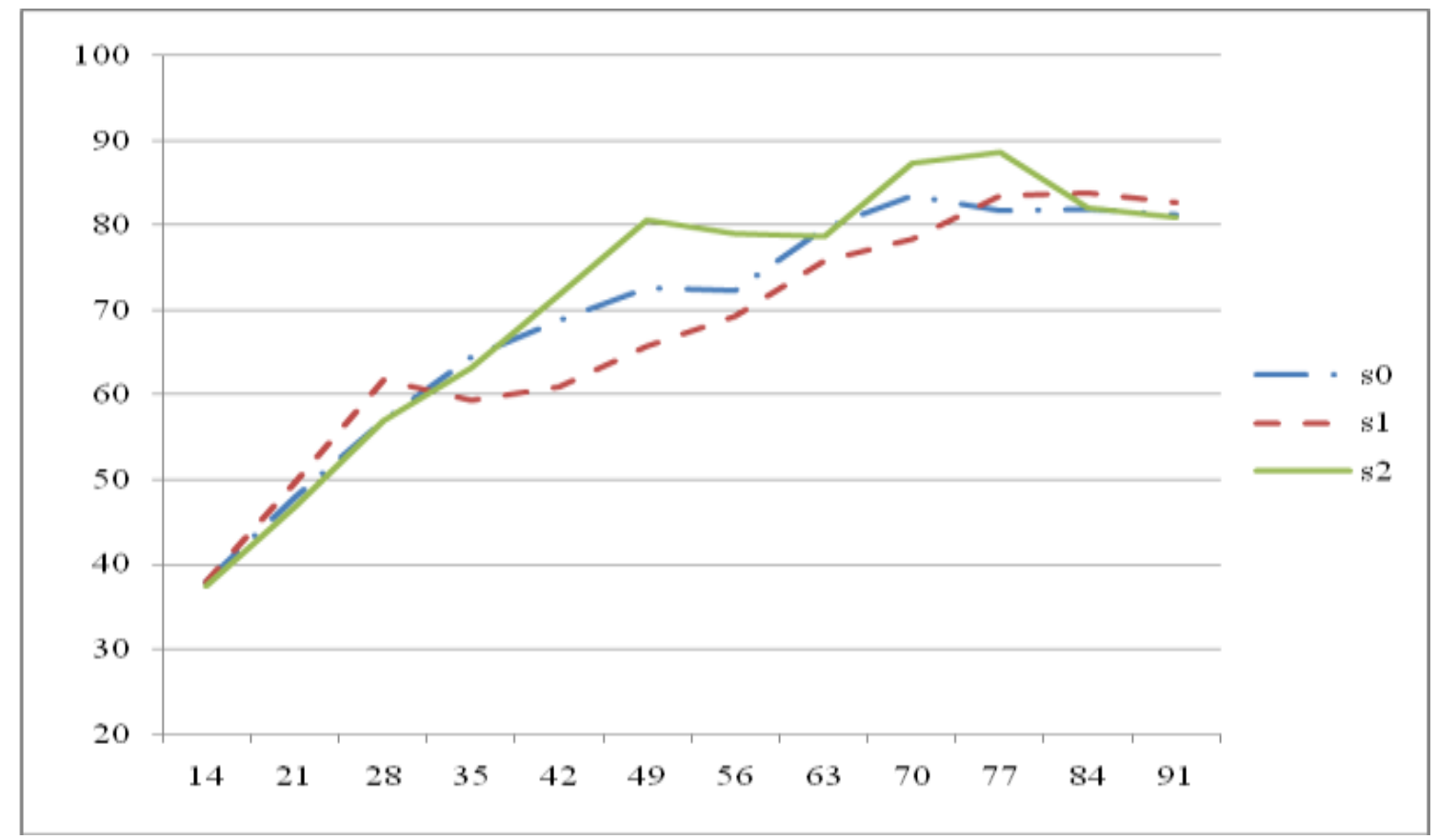

Notes: $\mathrm{S} 0=$ w/o submergence; $\mathrm{S} 1=$ Submerge at early vegetative stage (15-24 d.a.t); $\mathrm{S} 2=$ Submerge at late vegetative stage (35-44 d.a.t).

Gambar 1. Pengaruh Perendaman terhadap Rata-Rata Tinggi Tanaman Varietas IR64 dan IR64-Sub 1

Dari penelitian sebelumnya diketahui faktor lingkungan utama yang mempengaruhi toleransi tanaman padi terhadap rendaman adalah suhu dan kejernihan air, intensitas cahaya dan kandungan nitrogen dalam tanah (Palada, 1970 dalam Supartopo et al., 2008). Dalam kondisi air jernih intensitas cahaya dapat langsung masuk kedalam air dan diterima oleh tanaman.

Berbeda dengan respon tinggi tanaman, pola pertambahan jumlah anakan per pot akibat perendaman memiliki pola yang berbeda antar perlakuan (Gambar 2).
Pertambahan jumlah anakan per pot terhenti selama proses perendaman. Tanaman mulai pulih dari pengaruh perendaman setelah 11 hari dihentikannya perendaman. Hal yang sama juga terlihat pada parameter tinggi tanaman, dengan jangka waktu pemulihan yang sama. Setelah pulih terjadi peningkatan laju jumlah anakan pada tanaman yang diberi perlakuan dibandingkan kontrol. Pada waktu panen jumlah anakan pada perlakuan perendaman (S1 dan S2) lebih tinggi dari pada yang tidak mengalami perendaman (S0) (Gambar 2). 


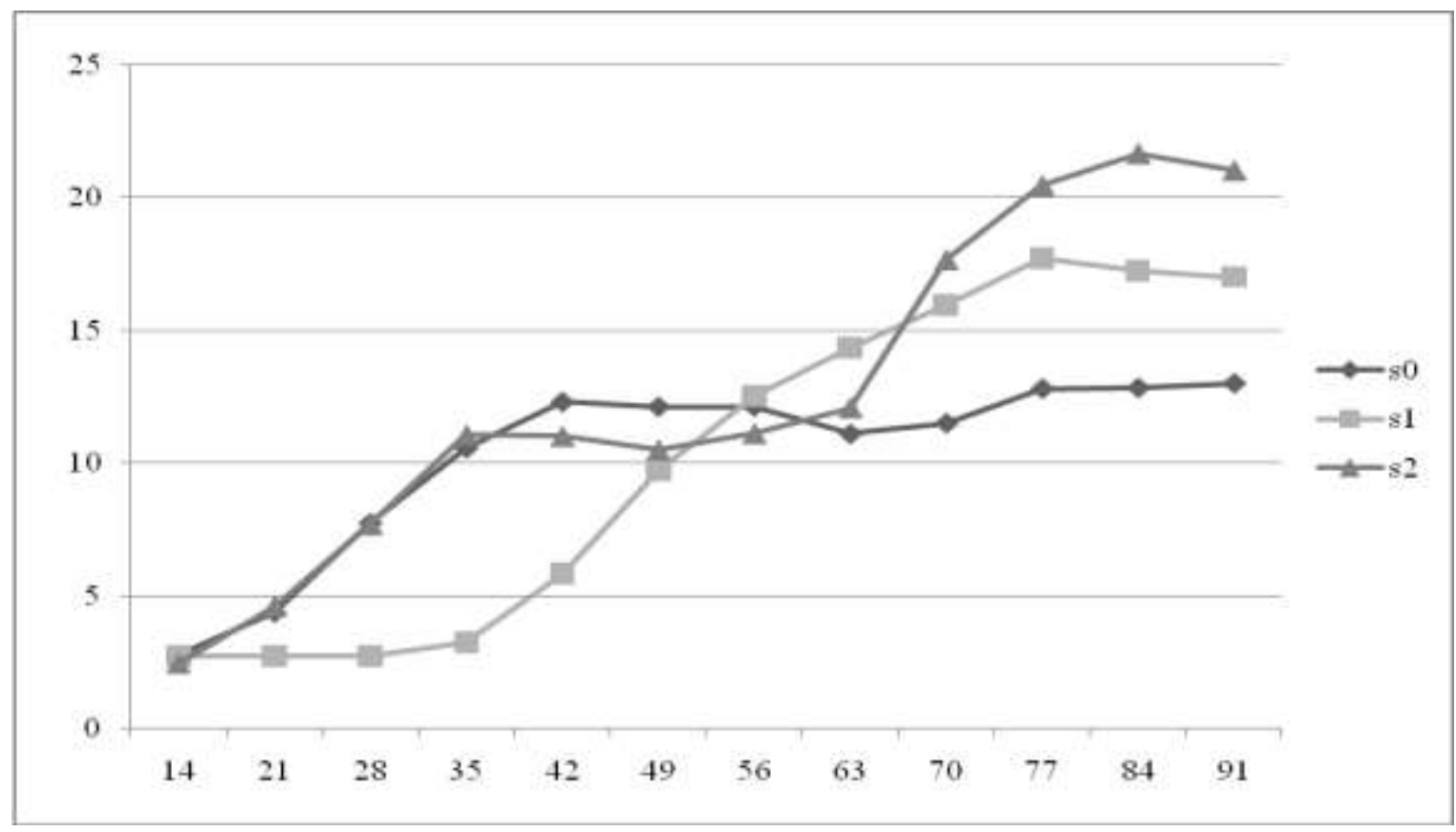

Gambar 2. Pengaruh Perendaman terhadap Rata-Rata Jumlah Anakan Varietas IR64 dan IR64-Sub 1

\section{Persentase kerusakan dan recovery pada perlakuan perendaman}

Kerusakan tanaman setelah perendaman

Akibat pengaruh perendaman, daun tanaman menjadi rusak dan hancur, terutama pada perlakuan $300 \mathrm{~kg}$ urea per/ha (F1). Persentase kerusakan tanaman akibat perlakuan perendaman disajikan pada Gambar 3. Pada Gambar 3 nampak bahwa perlakuan kontrol (F1) mengalami kerusakan daun mencapai 50\% dan $43.3 \%$ masing-masing pada IR64 dan IR64-Sub 1. Tingkat kerusakan tanaman dapat dilihat pada Foto 1.

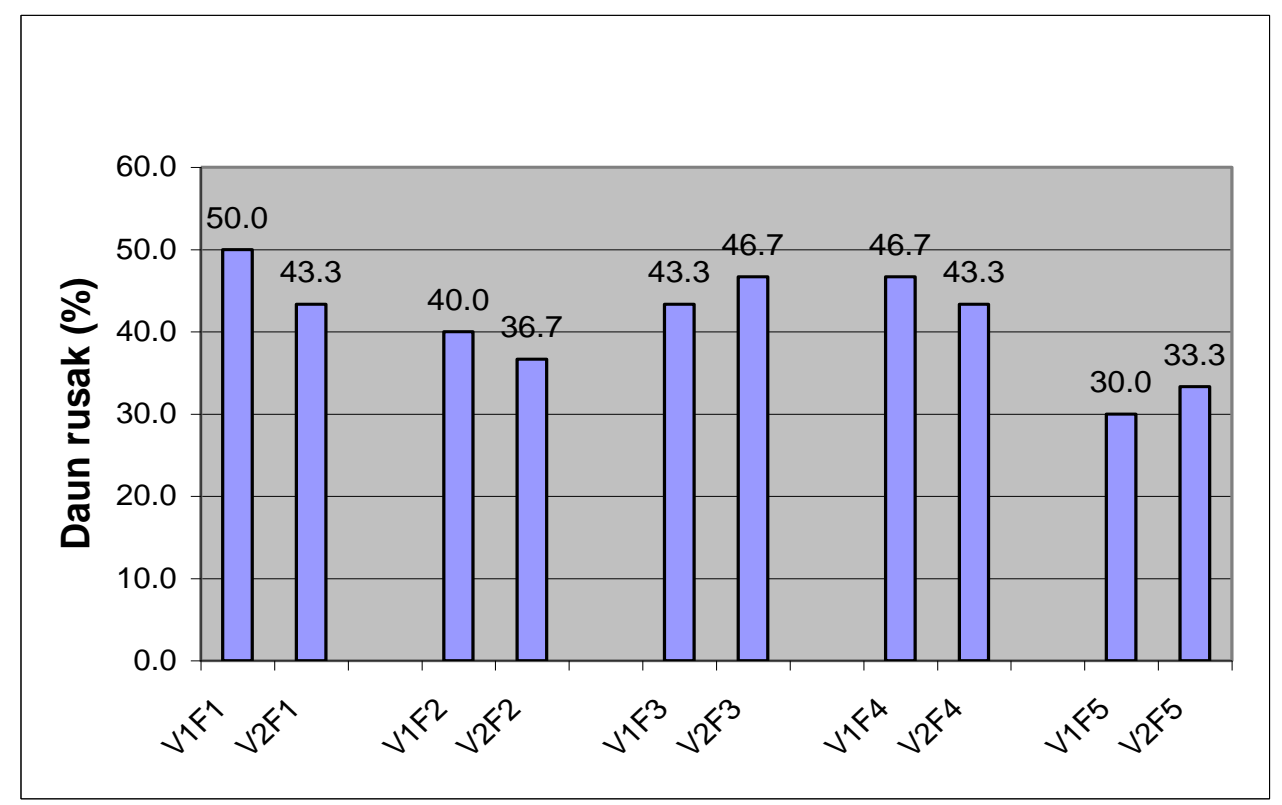

Keterangan: Daun rusak = jumlah daun mati (warna cokelat) x 100/jumlahdaun total per rumpun

Gambar 3. Pengaruh Pemberian Pupuk terhadap Kerusakan Daun Tanaman Padi yang Menerima Perlakuan Perendaman Selama 10 hari, Diukur Sesaat Setelah Pot Didrainasi. Muara, Bogor, MK2008 


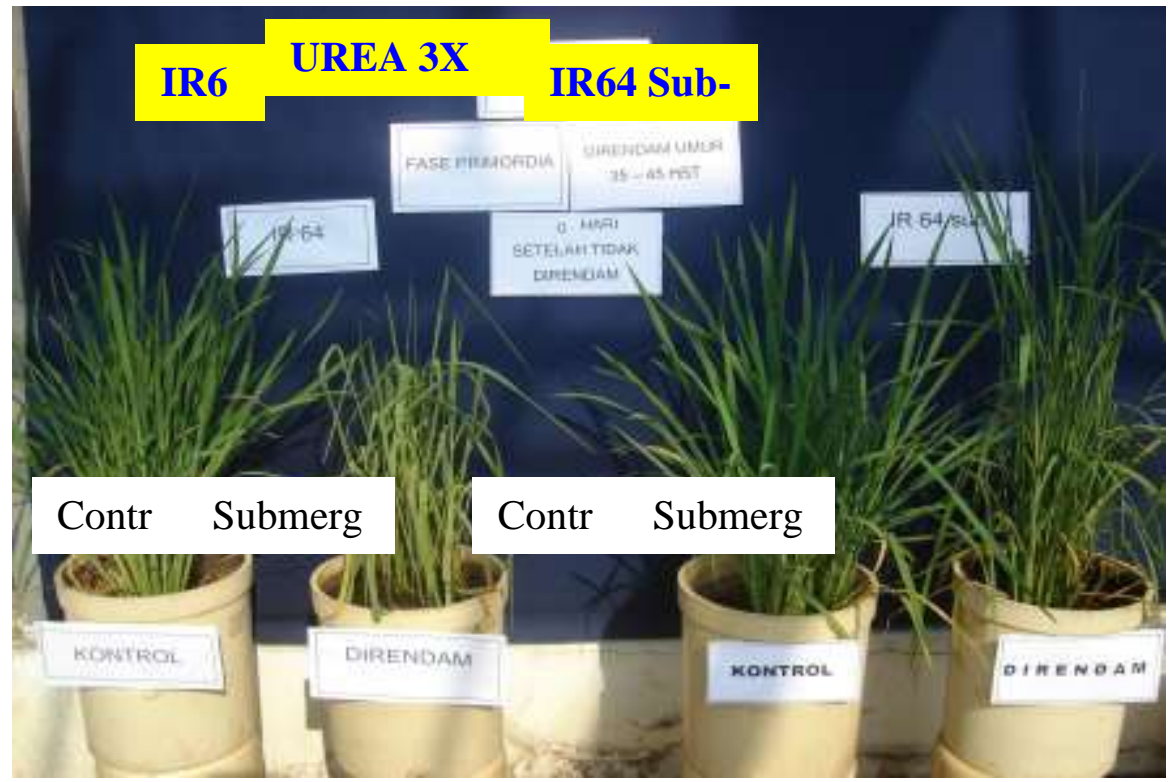

Foto 1. Penampilan Kedua Varietas IR64 dan IR64-Sub 1 Setelah Perendaman dan Kontrol

Penggunaan urea mudball (F2) mengurangi kerusakan daun menjadi $40.0 \%$ dan $36.7 \%$, pada masing-masing varietas. Tingkat kerusakan terendah ditemukan pada perlakuan $\mathrm{F} 5$, yaitu $\mathrm{F} 1+60 \mathrm{~kg} \mathrm{SiO} /$ ha. Dalam perlakuan ini tingkat kerusakan daun 30.0 dan $33.3 \%$. Dalam percobaan ini menunjukkan bahwa Mudball urea atau aplikasi silikat dapat meningkatkan ketahanan varietas padi akibat perendaman. Percobaan sebelumnya mengindikasikan bahwa aplikasi silikat meningkatkan ketahanan tanaman terhadap berbagai penyakit (Nasution and Santoso, 2007) dan hama (Makarim et al., 2007; Kartohardjono et al., 2007). Daun menjadi kuat karena jumlah cukup silikat juga dapat meningkatkan resistensi terhadap perendaman
Pemulihan tanaman setelah perendaman

Setelah 7 hari perendaman, daun-daun tanaman mulai pulih dengan derajat yang berbeda tergantung pada aplikasi pupuk. Perlakuan F1 (300 kg urea/ha) masing-masing untuk varietas IR64 dan IR64-Sub 1, menunjukan 16.7 dan $23.3 \%$ pemulihan. Mudball urea (F2) dan kompos (F3) tidak berpengaruh pada pemulihan daun. Kompos 1 ton/ha + urea $150 \mathrm{~kg} / \mathrm{ha}(\mathrm{F} 4)$ sedikit meningkatkan derajat pulih menjadi 23.3 dan $33.3 \%$. Daun tanaman Lebih cepat pulih juga terjadi pada perlakuan urea $300 \mathrm{~kg} / \mathrm{ha}+60 \mathrm{~kg} \mathrm{SiO}$ (F5) yaitu 36.7\% baik untuk IR64 atau IR64-Sub 1 (Gambar 4). Hal ini menunjukkan bahwa silikon ini sangat berguna untuk mengurangi kerusakan tanaman akibat perendaman.

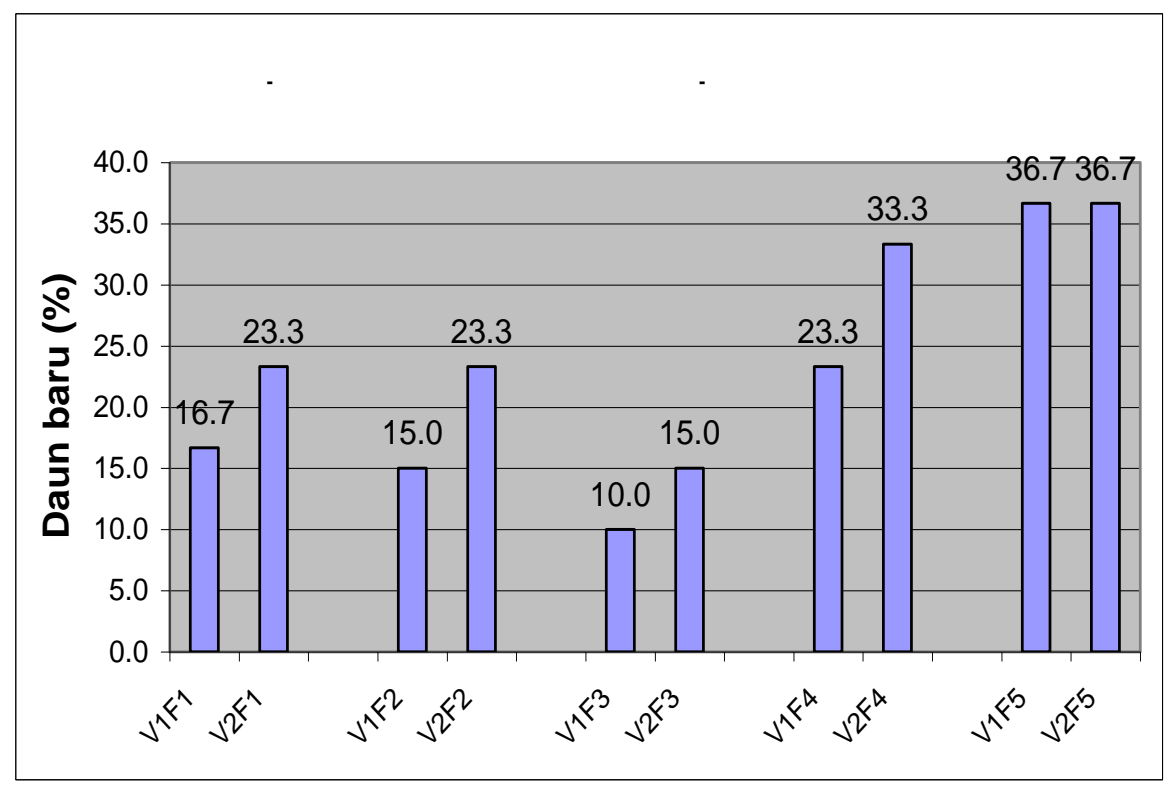

Gambar 4. Pengaruh Jenis dan Aplikasi Pupuk pada Pemulihan Daun Setelah Mengalami Kerusakan Akibat Perendaman (7 hari Setelah Perendaman) RK. Muara Bogor, 2008. 
Pengaruh waktu perendaman, aplikasi pupuk pada hasil padi (g/pot) dan komponen hasil IR64-Sub 1 dan varietas IR64

Pengaruh perlakuan perendaman dan aplikasi pupuk serta varietas pada hasil dan komponen hasil disajikan pada Tabel 3.

\section{Pengaruh perendaman}

Perendaman selama 7 hari pada percobaan pot ternyata dapat meningkatkan rata-rata hasil padi varietas IR64 dan IR64-Sub 1 (Tabel 3). Dalam kondisi normal, tanpa perendaman (S0) gabah isi tanaman adalah $30.8 \mathrm{~g} /$ pot. Dengan perendaman selama 10 hari di awal fase vegetatif (S1) dan di akhir fase vegetatif (S2) hasil padi masing-masing mencapai 40.7 dan 37.9 g/pot. Pada komponen hasil, jumlah malai meningkat secara signifikan akibat perendaman. Di akhir pertumbuhan vegetatif meningkatkan jumlah malai per pot seperti ditunjukkan pada Gambar 2. Jumlah bobot gabah per pot juga meningkat (Tabel 3). Pengaruh yang tidak berbeda nyata juga ditunjukkan pada bobot gabah 1000 butir dan persentase gabah isi. Kedua komponen itu menurun akibat pengaruh perlakuan perendaman. Komponen hasil lainnya tidak berpengaruh nyata.

Table 3. Pengaruh Perendaman Varietas IR64-Sub 1 dan IR64 di Muara, Bogor MT I 2008

\begin{tabular}{|c|c|c|c|c|c|c|c|}
\hline \multirow[t]{2}{*}{ Perlakuan } & Hasil & Jumlah malai $^{-1} /$ pot & $\begin{array}{c}\text { Panjang } \\
\text { malai }\end{array}$ & $\begin{array}{c}\text { Jumlah gabah isi } \\
\text { per malai }\end{array}$ & $\begin{array}{c}\text { Bobot } 1000 \\
\text { butir }\end{array}$ & $\%$ Gabah isi & Jumlah gabah per pot \\
\hline & $\left(\mathrm{g} \mathrm{GKG}^{-1} / \mathrm{pot}\right)$ & & $(\mathrm{cm})$ & & (g) & & \\
\hline \multicolumn{8}{|c|}{ Pengaruh rendaman } \\
\hline So & 30.8 & 12.9 & 22.4 & 101 & 23.5 & 95.4 & 1448 \\
\hline S1 & 40.7 & 16.9 & 23.7 & 104.1 & 22.6 & 87.3 & 2085 \\
\hline S2 & 37.9 & 21.1 & 21.1 & 85.3 & 20.3 & 86.4 & 2137 \\
\hline \multicolumn{8}{|c|}{ Pengaruh pemberian pupuk } \\
\hline F1 & 41.7 & 19 & 22.9 & 103.9 & 21.6 & 88.2 & 2229 \\
\hline $\mathrm{F} 2$ & 45.8 & 19.1 & 23.4 & 112.8 & 21.9 & 90.6 & 2326 \\
\hline F3 & 14.5 & 9.1 & 20.8 & 74.4 & 22.6 & 88.6 & 756 \\
\hline $\mathrm{F} 4$ & 32 & 16.5 & 21.9 & 88.2 & 22.2 & 91.5 & 1600 \\
\hline F5 & 48.4 & 21.1 & 23.1 & 104.8 & 22.2 & 89.5 & 2464 \\
\hline \multicolumn{8}{|c|}{ Pengaruh varietas } \\
\hline IR64 & 36 & 16.8 & 21.9 & 97.1 & 22.3 & 90.9 & 1818 \\
\hline IR64-Sub 1 & 36.9 & 17.1 & 22.9 & 96.5 & 21.9 & 88.5 & 1932 \\
\hline
\end{tabular}

\section{Pengaruh pemberian pupuk $\mathrm{N}$}

Pengaruh pemberian pupuk $\mathrm{N}$ terhadap hasil dan komponen hasil sangat nyata (Tabel 3). Pada perlakuan kontrol (pemberian $300 \mathrm{~kg}$ urea/ha 3x) (F1) lebih tinggi dibandingkan dengan pada perlakuan 2 ton kompos/ha (F3) dan perlakuan 1 ton kompos $+150 \mathrm{~kg}$ urea/ha (F4). Hal ini disebabkan rendahnya $\mathrm{N}$ total dalam 2 ton kompos. Kompos mengandung $1.8 \% \mathrm{~N}$, sehingga $\mathrm{N}$ yang digunakan melalui kompos hanya $36 \mathrm{~kg} \mathrm{~N} /$ ha atau setara dengan 80 $\mathrm{kg}$ urea / ha. Tingkat kompos biasanya digunakan oleh para petani adalah 2 ton / ha karena keterbatasan sumber bahan organik ini. Untuk musim berikutnya laju kompos akan ditingkatkan hingga 9 ton / ha atau setara dengan $300 \mathrm{~kg}$ urea / ha. Perlakuan kompos (F3) menghasilkan jumlah malai terendah, meningkatkan gabah isi per malai dan per pot, dan memiliki malai lebih pendek. Namun, tidak meningkatkan bobot 1000 butir dan persentase gabah isi. Pemberian silikat tambahan sebanyak $60 \mathrm{~kg} \quad \mathrm{SiO}_{2} / \mathrm{ha}$ bersama-sama dengan $300 \mathrm{~kg}$ urea/ha (F5) meningkatkan hasil gabah bersih dari $41.7 \mathrm{~g} /$ pot (F1) ke $48.4 \mathrm{~g} /$ pot. Pemberian silikat juga meningkatkan jumlah malai per pot dan panjang malai, sehingga jumlah butir gabah per pot meningkatkan. Mudball urea diberikan sekali pada 7 hst juga meningkatkan hasil, jumlah butir per malai terisi dan sedikit meningkatkan jumlah gabah per pot.

\section{$\underline{\text { Pengaruh varietas }}$}

Dalam percobaan ini varietas IR64 dan IR64-Sub 1 masing-masing menghasilkan 36 dan $36.9 \mathrm{~g}$ gabah isi /pot, tidak nyata berbeda. Jumlah malai per pot, panjang malai, jumlah butir gabah isi per malai, persentase gabah isi juga tidak berbeda antara dua varietas. Jumlah gabah per pot sedikit berbeda, di mana IR64-Sub 1 menghasilkan $6.27 \%$ lebih gabah isi dari IR64.

Sekelompok peneliti dari IRRI dan Universitas California, Davis telah berhasil mengidentifikasi gen padi yang menyebabkan tanaman padi mampu bertahan dalam genangan air. Penemuan ini sangat penting bagi pengembangan varietas baru padi yang tahan banjir. Dilaporkan bahwa keberhasilan penelitian tersebut berkat pemanfaatan biologi molekuler. Melalui teknik pemetaaan gen, Tim mengidentifikasi adanya suatu klaster yang terdiri dari 3 gen yang berhubungan erat dengan proses biologi yang menyebabkan padi rentan terhadap banjir atau memungkinkan tanaman dapat bertahan dalam rendaman air. Penelitian kemudian lebih difokuskan pada salah satu dari gen tersebut yang dikenal sebagai gen Sub 1A. Keberadaan gen Sub 1A bila dalam kondisi berlebih atau hiperaktif menyebabkan tanaman padi menjadi tahan dalam rendaman air. Lebih jauh lagi ditemukan bahwa ternyata gen tersebut mempengaruhi respon tanaman terhadap hormon seperti ethylene dan asam gibberelik yang berperan 
besar menyebabkan tanaman mampu bertahan dalam air. Dilaporkan bahwa penemuan tersebut memberikan harapan untuk meningkatkan ketersediaan pangan terutama bagi penduduk miskin di negara berkembang.

\section{KESIMPULAN}

1. Pengaruh perendaman pada pertumbuhan tanaman, hasil dan komponen hasil dari IR64 dan IR64-Sub 1 varietas padi di rumah kaca tidak berbeda nyata.

2. Pemberian Mudball urea dan silikat meningkatkan hasil gabah dan beberapa komponen hasil, serta dapat mengurangi kerusakan daun dan lebih cepat pulih setelah mengalami perendaman.

3. Perendaman menyebabkan tinggi tanaman tumbuh lebih cepat, sedangkan jumlah anakan stagnan dibandingkan tanpa perendaman.

4. Setelah mengalami perendaman kedua varietas pulih dan menghasilkan lebih banyak jumlah anakan dari yang tanpa perendaman.

\section{SARAN}

Diperlukan penelitian lebih mendasar/strategis tentang respon varietas tanaman terhadap rendaman, termasuk kualitas air rendamannya.

\section{REFERENCES}

Catling, D. 1992. Rice in deep water. Manila: International Rice Research Institute.pp54.

CGIAR (Consultative Group on International Agriculture Research). 2006. Intensified Research Effort Yields Climate-Resilient Agriculture To Blunt Impact of Global Warming, Prevent Widespread Hunger.Heattolerant Wheat, Flood-proof Rice, Satellites for Carbon Trading Among New Technologies.Press release.pp4.

Ella, E.S., N. Kawano, Y. Yamauchi, K. Tanaka, and A. M. Ismail. 2003. Blocking ethylene perception enhances flooding tolerance in rice seedlings. Funct. Plant Biol., 30:813-819.

Ito, O., E. Ella, and N. Kawano. 1999. Physiological basis of submergence tolerance in rainfed lowland rice ecosystem. Field Crops Res., 64:75-90.

Jackson, M. B. and P. C. Ram. 2003. Physiological and molecular basis of susceptibility and tolerance of rice plants to complete submergence. Annals of Botany, 91: 227-241.
Jackson, M.B., I. Waters, T. Setter, and H. Greenway. 1987. Injury to rice plants caused by complete submergence: A contribution of ethylene (ethane). $J$. Exp. Bot., 38:1826-1838.

Kartohardjono, A., Trisnaningsih, Anggiani, and Santoso. 2007. The effects of $\mathrm{SiO}_{2}$ on the intensity of Yellow rice stemborer Scirpophaga incertulas and blast disease Pyricularia grisea. Final report). P.T. Nusa Palapa Gemilang-ICRR (In Bahasa Indonesia).

Lee, T., and Y. Lin. 1996. Peroxidase activity in relation to ethylene-induced rice (Oryza sativa L.) coleoptile elongation. Bot. Bull. Acad. Sin., 37:239-245.

Mackill, D. J., H. T. Nguyen, and Jingxian Zhang.1999.Use of molecular markers in plant improvement programs for rainfed lowland rice. Field Crops Res., 64 : 177185.

Makarim, A. K., E. Suhartatik, A. Nasution, Trisnaningsih and Ikhwani. 2007. Efficacy testing of SIPPadi-HS silicate fertilizer on rice plant (Final report). P.T. Nusa Palapa Gemilang-ICRR (In Bahasa Indonesia).

Nugroho, K., A. Kusuma, Paidi, W. Wahdini, Abdurachman, H. Suhardjo dan IP. G. Widjaja-Adhi. 1993. Peta areal untuk pengembangan pertanian lahan pasang surut dan pantai. Proyek Penelitian Sumber Daya Lahan. Pusat Penelitian Tanah dan AgroKlimat. Badan Litbang Pertanian.

Nasution, A. and Santoso. 2007. The effects of silicate fertilizer on the intensity of blast disease attack caused by Pyricularaia grisea (Final report). P.T. Nusa Palapa Gemilang-ICRR (In Bahasa Indonesia). 12 pages.

Septiningsih, E. M., A. M. Pamplona, D. L. Sanchez, C. N. Neeraja, G. V. Vergara, S. Heuer, A. M. Ismail, and D. J. Mackill. 2008 Development of submergence tolerant rice cultivars: The Subl locus dan beyond. Ann Bot:(in press).

Supartopo, R. Hermanasari, Maulana, dan A. Haermansis. 2008. Uji rendaman galur-galur harapan rawa lebak. Prosiding seminar apresiasi hasil penelitian padi menunjang P2BN.pp. 697-704.

Widjaja-Adhi, IP. G. 1995. Potensi peluang dan kendala perluasanareal pertanian lahan rawa Kalimantan dan Irian Jaya. Makalah di sampaikan dalam Seminar Perluasan Areal Pertanian di KTI. Serpong 7-8 November 1995.

Widiarta, I. N. 2007. Loss and risk assessment: Irrigation Infrastructure and flood affecting areas in Indonesia. Final report. ICFORD-IRRI collaboration. 